\title{
Partitioning risks of tree mortality by modes of death in managed and unmanaged northern hardwoods and mixedwoods
}

\author{
by François Guillemette ${ }^{1 \%}$, Martin-Michel Gauthier ${ }^{1}$ and Rock Ouimet ${ }^{1}$
}

\begin{abstract}
We used a permanent sample plot network established to monitor the effects of forest management practiced in mature northern hardwood and mixedwood stands in Québec, Canada to address two important questions related to tree mortality: (1) How does partial cutting affect tree mortality? (2) Which variables best explain tree mortality by different modes of death (standing death, uprooting or stem breakage)? Decennial tree deaths were lower after partial cutting than in unharvested plots, but the annual proportion of tree death was similar $\left(1.25 \% \cdot y^{-r^{-1}}\right)$. At the tree level, a risk-product classification demonstrated the strongest evidence on influencing total mortality, followed by species, the presence of a $\log$ ging injury, and tree size. Annual temperature was the only climatic variable explaining variations in total risk of tree mortality, and always among the first three variables explaining differences among the three modes of death. The risk of standing death also increased with increasing annual precipitation, while the risk of stem breakage and, to a lesser extent, of being uprooted, decreased with increasing precipitation. Additionally, we found strong evidence to support the effect of the potassium/magnesium ratio of the humus layer on the risk of being uprooted. This information is critical to better understand tree mortality processes.
\end{abstract}

Key words: selection cutting, partial cutting, mortality, deadwood, stand dynamics.

\section{RÉSUMÉ}

Nous avons utilisé les données de placettes permanentes établies pour suivre les effets de l’aménagement forestier dans des peuplements matures à dominance feuillue au Québec (Canada) dans le but de répondre à deux questions relatives à la mortalité des arbres : (1) Comment la coupe partielle affecte-t-elle le taux de mortalité des arbres? (2) Quelles variables expliquent le mieux la mortalité des arbres feuillus selon qu'ils sont morts sur pied, déracinés ou ont un tronc rompu? La mortalité décennale était moindre après une coupe partielle que dans les placettes non traitées, mais la proportion annuelle d’arbres morts était la même dans les deux $\left(1,25 \%\right.$ année $\left.{ }^{-1}\right)$. Parmi les variable étudiées, la classe de risque et de produit potentiel de larbre feuillu influençait le plus la probabilité globale de mortalité; elle était suivie par lespèce, la présence d'une blessure de coupe, puis la dimension de l'arbre. La température annuelle était la seule variable climatique permettant d'expliquer la probabilité globale de mortalité des arbres, et l'une des trois variables les plus importantes pour les trois types de mort. Le risque de mourir sur pied augmentait aussi avec laugmentation des précipitations annuelles, tandis que celui de rupture du tronc et, dans une moindre mesure, celui dêtre déraciné diminuaient avec l'augmentation des précipitations. Finalement, nous avons observé que le risque de déracinement d’un arbre était influencé par le rapport potassium/magnésium dans la couche d'humus du sol. Ces informations sont importantes pour mieux comprendre les processus de mortalité des arbres.

Mots-clés : coupe de jardinage, coupe partielle, mortalité, bois mort, dynamique des peuplements.

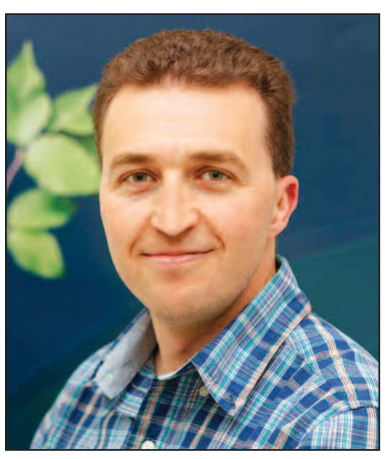

François Guillemette

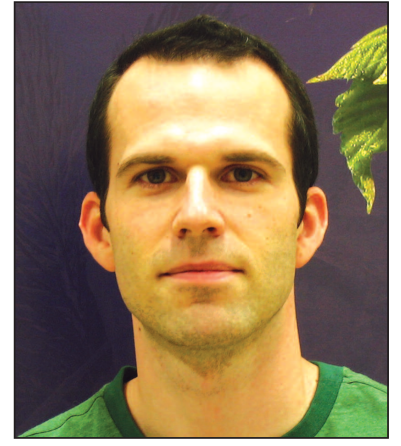

Martin-Michel Gauthier

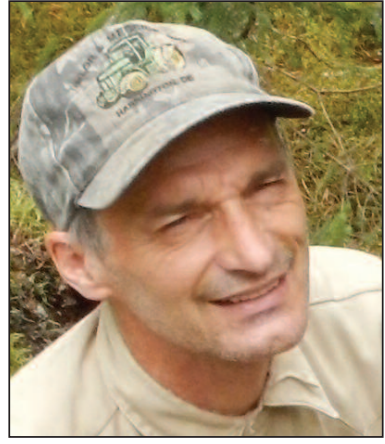

Rock Ouimet

${ }^{1}$ Ministere des Forêts, de la Faune et des Parcs, Direction de la recherche forestière, Québec, Québec G1P 3W8 *corresponding author : Francois.Guillemette@mffp.gouv.qc.ca 


\section{Introduction}

Tree mortality is an important process, both in terms of ecological functions (Franklin et al. 1987, 2002) and forest stand growth (Nyland 1996). Regarding the latter, information about tree mortality is often required to determine the feasibility of potential management options. The resulting dead trees have many ecological functions: they create environmental conditions favourable to the establishment and development of natural regeneration as well as new habitats for many animal species (Mannan et al. 1980, Hansen et al. 1991); they also influence the terrestrial biogeochemical cycles of many essential elements, including carbon (Hicke et al. 2012). Moreover, the amount of deadwood in a forest stand is often viewed as an important measure of structural complexity (McElhinny et al. 2005, Bauhus et al. 2009), and higher structural complexity is thought to promote biodiversity (Hansen et al. 1991).

However, as a component of forest stand growth, tree mortality is notoriously difficult to estimate (Fortin et al. 2008). The difficulty in forecasting mortality can be attributed to several factors, including its stochastic nature and rare occurrence (Flewelling and Monserud 2002), high inter- and intraspecific competition, and varying life cycles of tree species (Fortin et al. 2008). Moreover, some processes of tree mortality can be long and complex, such as the numerous diseases that eliminate less vigorous trees (Manion 1981). Further, there is a frequent lack of standardized tree health data to be found in conjunction with growth data obtained from permanent plots (Reid et al. 2016).

Despite these challenges, several studies have investigated tree mortality dynamics (e.g., Lines et al. 2010, Holzwarth et al. 2013, Martin et al. 2014, Bashir and MacLean 2015). Those of Holzwarth et al. (2013) and Martin et al. (2014) were designed to partition tree mortality into detailed processes, but were performed in a limited number of sites or forests. Therefore, the results of these studies are difficult to generalize over a large area in which environmental conditions are likely to differ. Indeed, tree mortality dynamics may differ according to soil conditions (Gitlin et al. 2006), topography (Ruel 2000, Bouchard et al. 2009) or climate (Allen et al. 2010, Canham and Murphy 2017). Understanding the effect of climate on forest dynamics is even more important in the context of climate change (Logan et al. 2011). Other studies on tree mortality dynamics (e.g., Lines et al. 2010, Bashir and MacLean 2015) have covered larger areas, which allowed more regional or climatic effects to be detected. Yet these studies were not necessarily designed to partition tree mortality into detailed processes related to the mode of death (standing death, uprooting, or stem breakage) or to forest management (Martin et al. 2014).

Our study alleviates some of the challenges in studying tree mortality dynamics by using long-term (10-year) data through a large network of permanent sample plots established to monitor the effects of forest management through partial cutting practiced over a large geographical area within temperate forests of Québec, Canada. Standardized measurements of tree mortality data taken within this network also allowed us to partition tree mortality into detailed processes and to examine the influence of partial cutting, soils, topography, and climate.
The goal of this study is to improve our understanding of tree mortality for both the purposes of timber management and how this relates to ecological attributes. The partition of mortality into modes of death helps to better understand which factors kill trees in different regions, and then to better adapt silvicultural objectives and methods, such as tree marking prior to a partial cut. We address two main questions. First, how does partial cutting affect tree mortality? Second, which tree-, stand-level, geographic or climatic variables best explain the risk of hardwood tree mortality and its partitioning into different modes of death? These two questions are based on the following biological hypotheses: (1) the risk of tree mortality follows a U-shaped trend, with higher mortality for smaller and larger trees; (2) partial cutting reduces tree mortality; (3) residual trees that were injured by logging are more likely to die; (4) shade-intolerant or mid-tolerant hardwood species are more susceptible to die than shade-tolerant hardwoods; (5) a risk and product classification of trees is useful to identify the risk of tree death; (6) climate and its geographic contributors affect the risk of mortality; and, trees located either (7) on a mountain top, (8) on nutrient-deficient soils, (9) on a lower site index, or (10) on dryer sites are at higher risk of dying.

\section{Material and Methods Study area}

From 1995 to 1999, a network of 930 permanent sample plots was established in uneven-aged northern hardwood and mixedwood stands within the temperate forest zone of Québec, Canada (Fig. 1). Although the exact disturbance history of each stand is unknown, regional history tells us that these stands were old-growth or mature at the beginning of the study. However, most of them were probably visited once or twice in the previous decades for a selective harvest of scattered large-diameter and good-quality trees. The network covers a latitudinal gradient of mean annual temperature $\left(0.4-4.2^{\circ} \mathrm{C}\right)$ and a longitudinal gradient (west-east) of annual precipitation $(880-1415 \mathrm{~mm})$. In hardwood stands, the most abundant tree species include sugar maple (Acer saccharum Marshall, SM), yellow birch (Betula alleghaniensis Britton, YB), and American beech (Fagus grandifolia Ehrhart, $\mathrm{AB}$ ). In mixedwood stands, balsam fir (Abies balsamea [L.] Miller, BF) is the most abundant conifer species, often associated with YB. Mean pre-harvest stand basal area was $28.0 \pm 0.3 \mathrm{~m}^{2} \cdot \mathrm{ha}^{-1}$ (mean \pm standard error) and mean tree density was $518 \pm 8$ stems.ha- ${ }^{-1}$, both for stems with a diameter at breast height $(\mathrm{DBH}$, measured at a height of $1.3 \mathrm{~m}$ ) of at least $9.1 \mathrm{~cm}$.

\section{Experimental design and treatments}

The 930 plots were distributed among 276 cutblocks harvested from 1995 to 1999 . Of these, 673 were treated by partial cutting the same year (operational selection cutting); the remaining 257 were protected from logging (unharvested) in an incomplete block design. A detailed description of the plots and the network has been published by Guillemette $e t$ al. (2013). Briefly, the plots are $400 \mathrm{~m}^{2}$ in area and contain standard forestry metrics for permanent sample plots, plus a riskproduct classification (RP, ranked from 1 to 4 for hardwoods) that was used for tree marking. Healthy, good-quality trees, 


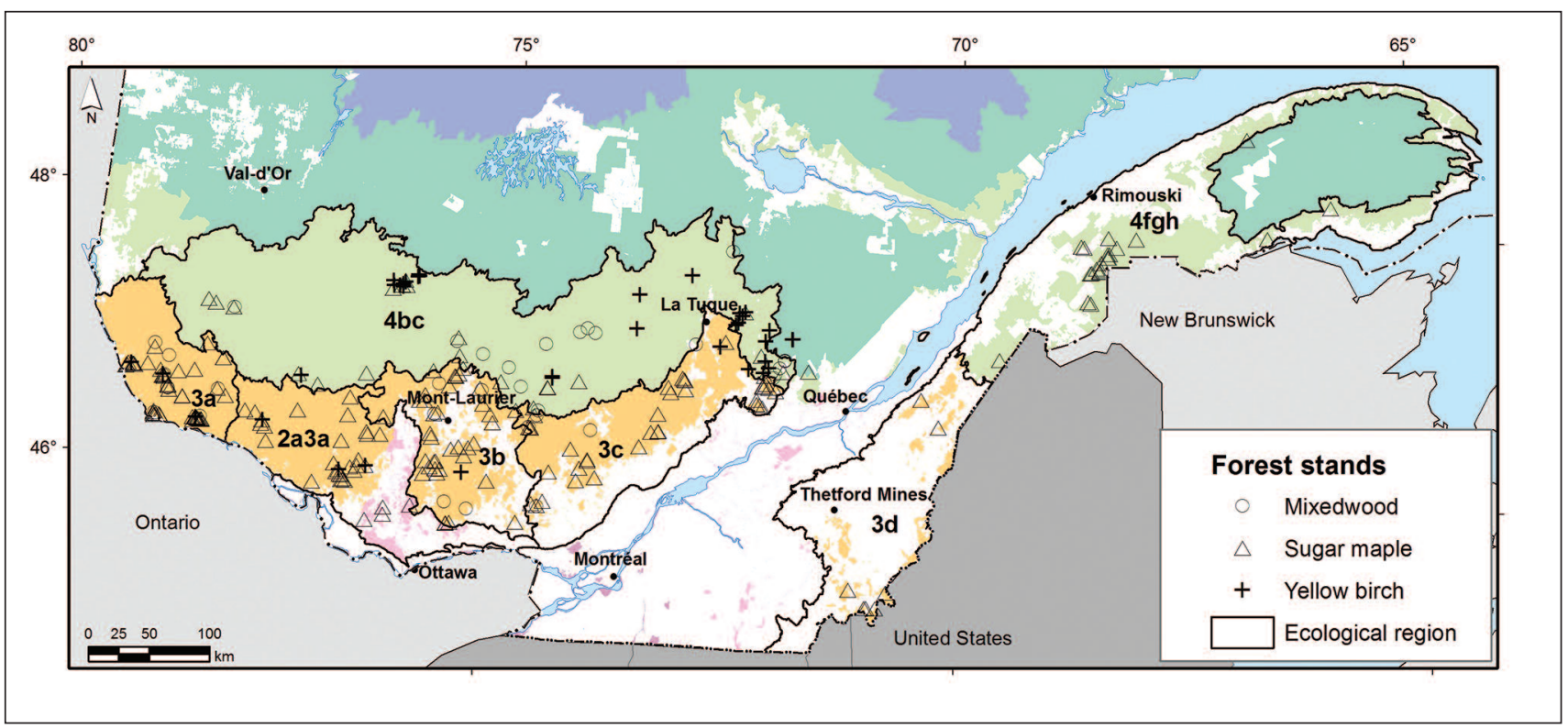

Fig. 1. Location of the cutblocks according to their ecogroup, i.e., the dominant species of the forest stand and ecological region. Coloured areas indicate public forest lands, according to the bioclimatic domains of Saucier et al. (2009): Pink, sugar maple-basswood (Tilia americana L.); orange, sugar maple-yellow birch; green, balsam fir-yellow birch; turquoise, balsam fir-paper birch (Betula papyrifera Marshall]; purple, black spruce (Picea mariana [Miller] B.S.P.] —moss.

the trunk of which contains a potential sawlog, are in RP class 1 and considered as "acceptable growing stock" (AGS). Trees in RP class 2 are healthy, but do not have a potential sawlog due to branches, a sweep or a crook in their trunk. Trees in RP class 3 have a major defect (crown dieback, decay or a major scar), but a trunk that still contains a potential sawlog. Finally, the most defective trees, considered as cull trees, are in RP class 4 . Trees in RP classes 3 and 4 are affected by disease. For further details, see Majcen et al. (1990), Fortin et al. (2008) or Guillemette et al. (2008). Tree death was partitioned into three modes: standing death, uprooting or stem breakage. Measurements were taken prior to cutting, immediately after cutting and, again, 5 and 10 years after cutting. In treated plots, $25 \%$ to $35 \%$ of the initial basal area was harvested following tree marking in each $10-\mathrm{cm} \mathrm{DBH}$ class to increase the proportion of quality trees in the residual stand. Mean postharvest stand basal area was $19.0 \pm 0.3 \mathrm{~m}^{2} \cdot \mathrm{ha}^{-1}$, and mean tree density was $338 \pm 8$ stems $\cdot \mathrm{ha}^{-1}$ in the treated plots.

\section{Climatic, geographic, and soil variables}

Several climatic variables (30-year running average for 1971-2000) were estimated for each plot, and then averaged for each cutblock using BioSIM software (Régnière and SaintAmant 2008) which estimates local climatic conditions based upon data from the closest weather stations (mean distance: $30 \mathrm{~km}$; range: 3 to $76 \mathrm{~km}$ ) that are adjusted to the geographic coordinates of the plot, including elevation. These variables included annual precipitation, growing season precipitation, annual temperature, growing season temperature, and aridity index (Table 1). In addition to the geographical location of the cutblock (longitude, latitude, elevation), a wind exposure index (TOPEX, Chapman 2000) was obtained for every plot as described in Waldron et al. (2013) using the routine of Ruel et al. (2002). TOPEX was a significant variable in explaining the risk of windthrow in the boreal forest of eastern Québec (Waldron et al. 2013). An index of the accumulation of flowing water in the soil matrix (FLOWAT) in the plot was calculated using a topographic raster and the flow direction and flow accumulation tools in the Spatial Analyst of ArcMap 9.2 (ESRI Inc., Redlands, California). This index is the area $\left(\mathrm{m}^{2}\right)$ of the plot, plus the area of adjacent $20 \mathrm{~m} \times 20 \mathrm{~m}$ cells that would drain their water into the cell of the plot based upon the topographic map (scale 1:20 000, 10-m elevation contours). Cutblocks were combined into nine ecogroups (Fig. 1) according to three criteria: (1) their dominant species composition: SM, YB, or mixedwood (MW); (2) the ecological region (Saucier et al. 2009, Fig. 1); and (3) in a particular case, the disturbance history (i.e., a severe regional windthrow that occurred in July 2006 in ecogroup SM 3a). From 2010 to 2013, 790 of the plots were revisited for soil sampling and height measurements on a sample of trees. Soil depth was measured $(13-101 \mathrm{~cm})$. A composite soil sample was also collected from two pits within each plot for the $\mathrm{H}$ horizon of the forest floor and the uppermost $10 \mathrm{~cm}$ of the $\mathrm{B}$ horizon. Soil collection procedures and physical and chemical analyses were the same as those described by Gauthier et al. (2015). The first selection of soil chemical variables to test was based on results from Ouimet $e t$ al. (2013) and Sullivan et al. (2013) on SM health. From the upper $10 \mathrm{~cm}$ of $\mathrm{B}$ horizon mineral soil, the selected variables were $\mathrm{Ca}, \mathrm{Mg}$ and total base cation saturation, the $\mathrm{Ca} / \mathrm{Mg}$ ratio, the $\mathrm{K} / \mathrm{Mg}$ ratio, and $\mathrm{pH}$ (in $\mathrm{H}_{2} \mathrm{O}$ ). From the forest floor $\mathrm{H}$ horizon, the selected variables were $\mathrm{Ca}$ saturation, $\mathrm{Ca} / \mathrm{Mg}$ ratio, $\mathrm{K} / \mathrm{Mg}$ ratio, and $\mathrm{pH}$ (in $\mathrm{H}_{2} \mathrm{O}$ ). A site index (SI) was also calculated at the cutblock-level, that is, the mean height of a $40-\mathrm{cm} \mathrm{DBH}$ tree of the dominant species, either SM or YB, according to the ecogroup (Table 2). This variable was used as a proxy for site index (SI) because the typical use of an age and height relationship for SI was not possible due to the unevenaged structure of the stands. Water holding capacity (WHC) was calculated using soil depth, stone fraction content, and water content at field capacity, according to Ung et al. (2001, equation 4). 
Table 1. Average characteristics of the studied cutblocks according to their ecoregion. Abbreviations: TOPEX, topographic exposure; FLOWAT, index of the accumulation of flowing water in the soil matrix; Elev., elevation; WHC, water holding capacity; Grow. seas., growing season; SI, site index; MW, mixedwood; SM, sugar maple; YB, yellow birch

\begin{tabular}{|c|c|c|c|c|c|c|c|c|c|c|}
\hline \multirow[b]{2}{*}{ Ecogroup } & \multirow[b]{2}{*}{ TOPEX } & \multirow{2}{*}{$\begin{array}{c}\text { FLOWAT } \\
\mathbf{m}^{2 \star}\end{array}$} & \multirow{2}{*}{$\begin{array}{c}\text { Elev. } \\
\mathbf{m}\end{array}$} & \multicolumn{2}{|c|}{ Precipitation (mm) } & \multicolumn{2}{|c|}{ Temperature $\left({ }^{\circ} \mathrm{C}\right)$} & \multirow{2}{*}{$\begin{array}{c}\text { Aridity } \\
\text { mm }\end{array}$} & \multirow{2}{*}{$\begin{array}{c}\text { WHC } \\
\text { mm }\end{array}$} & \multirow{2}{*}{$\begin{array}{l}\text { SI } \\
\mathbf{m}\end{array}$} \\
\hline & & & & Annual & Grow. seas. & Annual & Grow. seas. & & & \\
\hline MW & 2.8 & 1600 & 402 & 1048 & 479 & 2.2 & 14.0 & 3.4 & 54 & 19.1 \\
\hline SM 2a3a & -5.1 & 1600 & 319 & 944 & 429 & 3.1 & 14.6 & 5.1 & 65 & 22.5 \\
\hline SM 3a & -13.2 & 1200 & 356 & 964 & 479 & 3.1 & 14.3 & 4.5 & 37 & 21.2 \\
\hline SM $3 b$ & -1.4 & 1600 & 340 & 1032 & 458 & 2.8 & 14.4 & 3.9 & 64 & 22.8 \\
\hline SM $3 c$ & -9.6 & 1600 & 375 & 1134 & 507 & 2.3 & 14.0 & 2.7 & 72 & 21.5 \\
\hline SM 3d & 2.2 & 5600 & 543 & 1251 & 563 & 2.9 & 13.8 & 1.9 & $65 \dagger$ & $20.8 \dagger$ \\
\hline SM 4bc & -9.5 & 1600 & 429 & 1026 & 454 & 1.6 & 13.8 & 3.1 & 67 & 20.2 \\
\hline SM 4 fgh & -22.7 & 1600 & 368 & 1145 & 499 & 1.9 & 13.7 & 2.8 & - & - \\
\hline $\mathrm{YB}$ & -3.9 & 1800 & 414 & 1025 & 459 & 1.6 & 13.8 & 3.1 & 63 & 19.6 \\
\hline Global & -7.1 & 1600 & 377 & 1039 & 473 & 2.4 & 14.1 & 3.6 & 58 & 21.0 \\
\hline
\end{tabular}

${ }^{*}$ Median rather than mean value because of the strongly right-skewed distribution of data.

${ }^{\dagger}$ Based on data collected from 2 of the 7 cutblocks in this ecogroup.

Table 2. Average soil chemical properties of $\mathrm{H}$ and $\mathrm{B}$ horizons that were collected in the study cutblocks according to their ecoregion. Abbreviations: Ca, calcium; st., saturation; BS, base saturation; Mg, magnesium; K, potassium; MW, mixedwood; SM, sugar maple; YB, yellow birch

\begin{tabular}{|c|c|c|c|c|c|c|c|c|c|c|}
\hline \multirow[b]{2}{*}{ Ecogroup } & \multicolumn{4}{|c|}{ H horizon } & \multicolumn{6}{|c|}{ B horizon } \\
\hline & $\underset{(-\log [\mathbf{H}+])}{\mathbf{p H}}$ & $\begin{array}{c}\text { Ca st. } \\
(\%)\end{array}$ & $\begin{array}{c}\mathrm{Ca} / \mathrm{Mg} \\
\text { ratio }\end{array}$ & $\begin{array}{c}\mathrm{K} / \mathrm{Mg} \\
\text { ratio }\end{array}$ & $\underset{(-\log [\mathbf{H}+])}{\mathrm{pH}}$ & $\begin{array}{c}\text { Ca st. } \\
(\%)\end{array}$ & $\begin{array}{c}\text { Mg st. } \\
(\%)\end{array}$ & $\begin{array}{c}\text { BS } \\
(\%)\end{array}$ & $\begin{array}{c}\mathrm{Ca} / \mathrm{Mg} \\
\text { ratio }\end{array}$ & $\begin{array}{l}\mathrm{K} / \mathrm{Mg} \\
\text { ratio }\end{array}$ \\
\hline MW & 4.3 & 55.7 & 7.8 & 2.0 & 5.0 & 18.3 & 3.1 & 24.2 & 9.6 & 2.8 \\
\hline SM 2a3a & 4.7 & 66.1 & 10.8 & 1.8 & 5.2 & 28.7 & 4.0 & 36.2 & 11.9 & 2.5 \\
\hline SM 3a & 4.6 & 62.5 & 9.4 & 2.0 & 5.0 & 19.0 & 4.0 & 26.7 & 8.3 & 2.8 \\
\hline SM 3b & 4.7 & 64.4 & 12.0 & 1.4 & 5.2 & 31.9 & 4.3 & 40.9 & 12.1 & 2.2 \\
\hline SM $3 c$ & 4.4 & 52.8 & 9.9 & 2.2 & 5.0 & 16.6 & 3.1 & 22.9 & 8.7 & 3.0 \\
\hline SM $3 d \dagger$ & 4.7 & 51.1 & 9.3 & 2.2 & 4.8 & 19.0 & 2.9 & 24.5 & 8.3 & 3.0 \\
\hline $\mathrm{SM} 4 \mathrm{bc}$ & 4.6 & 57.7 & 7.9 & 2.1 & 5.1 & 15.4 & 3.2 & 21.9 & 7.9 & 3.1 \\
\hline SM 4fgh & - & - & - & - & - & - & - & - & - & - \\
\hline $\mathrm{YB}$ & 4.4 & 58.4 & 7.4 & 2.3 & 5.0 & 16.9 & 3.3 & 23.2 & 8.4 & 2.8 \\
\hline Global & 4.5 & 59.8 & 9.4 & 2.0 & 5.1 & 21.1 & 3.6 & 28.1 & 9.5 & 2.7 \\
\hline
\end{tabular}

${ }^{\dagger}$ Data collected from 2 of the 7 cutblocks in this ecogroup.

Statistical analyses and model selection

To address our first question, we calculated the average number of new dead trees per hectare from the 10-year measurement period, i.e., the trees that died during the 10-year period after cutting, for every cutblock and treatment and conducted a two-way analysis of covariance (ANCOVA) using a SAS procedure (SAS Institute Inc. 2008). The ANCOVA tested for significant differences due to treatments, ecogroups, and their interaction. The cutblocks were treated as random effects in the analyses. Tests were performed first by combining all merchantable size classes (DBH $\geq 9.1 \mathrm{~cm}$ ), then by using only trees with $\mathrm{DBH} \geq 29.1 \mathrm{~cm}$ to account for deadwood production of moderate-sized and large trees. The number of dead trees was log-transformed to meet homoscedasticity assumptions for the ANCOVA. However, the values presented in the results are the observed means, rather than their log-transformed estimates. Initial number of trees in the plot was included as a covariate in the analysis.
To address our second question, the probabilities of hardwood tree mortality (13 381 initial living trees) were modelled on various scales to identify which tree- or stand- level, geographic or climatic variables best explained variation in tree mortality and the distribution of tree modes of death (standing death, uprooting or stem breakage). Softwood species were too scarce in most cutblocks to be analyzed within the same statistical models. Candidate models were first calibrated to estimate the global probability for all dead trees over a 10 -year period. Then they were calibrated to estimate the 10 -year probabilities of each mode of death: standing death (921 dead trees), uprooting (251 dead trees) and stem breakage (340 dead trees).

The main statistical approach that was applied to the data was to compare the Akaike Information Criteria (AIC; Burnham and Anderson 2002) obtained from a list of 16 candidate models, each calibrated with a generalized linear mixed model using a complementary log-log link function with the 
GLIMMIX procedure (SAS Institute Inc. 2008). AIC was calculated before testing the random effect of cutblock. Many variables can contribute directly or indirectly to explaining mortality of individual trees (Hamilton 1986, Vanclay 1994). The candidate models were formulated in the following manner. First, two sets of models (models 1 to 11 , and models 12 to 16 ) were calibrated using either the complete dataset (930 plots) or the reduced dataset (790 plots) containing field information on soil properties and site index. Second, a reference model (either model 1 or model 12) was formulated for both datasets with the following plot-level or tree-level variables: $\mathrm{DBH}$ (in $\mathrm{mm}$ - hypothesis 1), treatment (partial cut or unharvested - hypothesis 2), the presence of a logging injury on the tree (hypothesis 3), species (three main species: $\mathrm{SM}, \mathrm{YB}$ and $\mathrm{AB}$ ) or species group (other shade-tolerant hardwoods - STH, shadeintolerant hardwoods - SIH, see Appendix; hypothesis 4), and the RP class (hypothesis 5). Most of these variables had been used previously in a model aimed at predicting tree mortality in the study area (Fortin et al. 2008). Logging injury was added because it affects mortality probability (Guillemette et al. 2008). Third, additional models were formulated either to remove one of the previous variables in order to determine its effect on the change of AIC, or to add one or two of the cutblock-level variables related to the other hypotheses regarding the effects of climate (hypothesis 6), of topography (TOPEX or FLOWAT - hypothesis 7), soil chemical properties (hypothesis 8), site index (hypothesis 9) or soil waterholding capacity (hypothesis 10). In addition, a full model was formulated with both datasets (models 11 and 16).

Due to the large number of potential climatic, geographic or soil variables, and to the expected correlations between some of these continuous variables, a principal component cluster analysis was performed with the VARCLUS procedure (SAS Institute Inc. 2008) to identify clusters of variables. Within each cluster, a variable with one of the lowest correlations among clusters and with one of the highest correlations within the cluster was selected as a potential variable for the candidate models.

Two methods were used to rank the importance of the explanatory variables within a set of candidate models: one with AIC values and one with $P$-values. First, the difference in AIC (difAIC ${ }_{x-y}$ ) of the model representing the variable of interest $(\mathrm{x})$ compared to the reference model ( $\mathrm{y}$, either model 1 or 12) was calculated. Models then were ranked according to difAIC ${ }_{x-y}$, considering that a model with a smaller AIC is better because it maximizes the likelihood value of the model. Because difference between a particular model and its reference comprises only one or two variables, the difAIC ${ }_{x-y}$ values were assumed to represent the contribution of the variable(s) of interest. We interpreted these differences similarly to Burnham and Anderson (2002), namely that an absolute
difAIC $_{\mathrm{x}-\mathrm{y}}<2$ indicates little support that the two models were different, while an absolute difAIC $\mathrm{x}_{\mathrm{x}-\mathrm{y}}>10$ indicates very strong evidence that both models were different. We did not use the multimodel inference method of Burham and Anderson (2002), because it requires a much more balanced set of candidate models than the ones formulated for the purpose of this study. We based our method of interpretation on similar concepts, but using the particular case of only one candidate model being nested in the other candidate model.

The second method used to rank explanatory variables was using their $P$-values obtained with the full models and after testing the random effect of cutblock. This statistic indicates the strength of evidence that there is some association between the dependent and an independent variable (Murtaugh 2014). $P$-values were also used for multiple comparisons among different levels for a categorical variable. In this case, they were adjusted with a simulation method available in SAS to account for the multiplicity of the tests (Simulate; Westfall et al. 2011).

\section{Results}

Influence of partial cutting on tree mortality

The decennial number of dead trees $(\mathrm{DBH} \geq 9.1 \mathrm{~cm})$ was significantly lower following partial cutting than in unharvested plots $(P=0.011$, Table 3$)$. For all ecogroups combined, mor- 
Table 4. Results of the principal component analysis, with the coefficient of determination $\left(R^{2}\right)$ of each variable within the cluster, and of each variable with the next closest cluster. Within each of the 6 clusters, the variable in bold characters was selected for modelling. Abbreviations defined in Tables 1 and 2

\begin{tabular}{|c|c|c|c|}
\hline \multirow[b]{2}{*}{ Cluster } & \multirow[b]{2}{*}{ Variable } & \multicolumn{2}{|c|}{$\mathbf{R}^{2}$} \\
\hline & & $\begin{array}{l}\text { within } \\
\text { the } \\
\text { cluster }\end{array}$ & $\begin{array}{l}\text { with the } \\
\text { next closest } \\
\text { cluster }\end{array}$ \\
\hline \multirow[t]{6}{*}{1} & B hor., Ca st. & 0.8871 & 0.5158 \\
\hline & B hor., BS & 0.8453 & 0.5412 \\
\hline & $\mathrm{B}$ hor., $\mathrm{Ca} / \mathrm{Mg}$ ratio & 0.6654 & 0.0996 \\
\hline & B hor., $\mathrm{pH}$ & 0.7559 & 0.2045 \\
\hline & $\mathrm{H}$ hor., $\mathrm{Ca} / \mathrm{Mg}$ ratio & 0.4139 & 0.1150 \\
\hline & $\mathrm{H}$ hor., $\mathrm{pH}$ & 0.3995 & 0.1524 \\
\hline \multirow[t]{5}{*}{2} & Latitude & 0.5228 & 0.1103 \\
\hline & Elevation & 0.7029 & 0.0958 \\
\hline & Annual temp. & 0.8391 & 0.1037 \\
\hline & Grow. seas. temp. & 0.8723 & 0.2296 \\
\hline & SI & 0.5192 & 0.1408 \\
\hline \multirow[t]{4}{*}{3} & Longitude & 0.6305 & 0.1262 \\
\hline & Annual precip. & 0.9083 & 0.0323 \\
\hline & Grow. seas. precip. & 0.4351 & 0.0353 \\
\hline & Aridity & 0.8014 & 0.4177 \\
\hline \multirow[t]{4}{*}{4} & B hor., Mg st. & 0.5658 & 0.2066 \\
\hline & $\mathrm{B}$ hor., $\mathrm{K} / \mathrm{Mg}$ ratio & 0.6857 & 0.3288 \\
\hline & H hor., Ca st. & 0.5620 & 0.2813 \\
\hline & $\mathrm{H}$ hor., $\mathrm{K} / \mathrm{Mg}$ ratio & 0.6631 & 0.1610 \\
\hline \multirow[t]{2}{*}{5} & TOPEX & 0.5992 & 0.0385 \\
\hline & FLOWAT & 0.5992 & 0.0117 \\
\hline 6 & WHC & 1.0000 & 0.0285 \\
\hline
\end{tabular}

tality accounted for $49.9 \pm 2.6$ trees.ha ${ }^{-1}$ (1.25\% of total density per year) in the first 10 years following partial cutting, compared to $65.0 \pm 3.9$ trees.ha ${ }^{-1}\left(1.25 \% \cdot y^{2}\right.$ ar $^{-1}$ of total density) in unharvested plots (mean \pm standard error). Mortality also varied among ecogroups $(P<0.001)$, but there was no interaction between partial cutting and ecogroup $(P=0.498)$. First, mortality in ecogroup SM 3a was significantly higher than in ecogroups YB, SM 4fgh, and SM 4bc. Second, mortality in ecogroup SM 4 fgh was significantly lower than in ecogroups YB, MW, SM 2a3a, SM 3b, SM 3c, and SM 4bc. Results were similar for larger trees $(\mathrm{DBH} \geq 29.1 \mathrm{~cm}$, Table 3$)$. Mortality was higher in unharvested plots $(20.3 \pm 1.7$ larger trees.ha ${ }^{-1}$ or $1.35 \% \cdot$ year $^{-1}$ of total density) than following partial cutting $\left(11.3 \pm 0.9\right.$ larger trees.ha ${ }^{-1}$ or $1.26 \% \cdot$ year $^{-1}$ of total density; $P=0.005)$. Again, mortality varied among ecogroups $(P<0.001)$, but only for higher mortality in ecogroup SM 3a compared to ecogroups SM 2a3a, SM 3c, SM 4bc, SM 4fgh, and $\mathrm{YB}$.

\section{Clusters of correlated variables}

Correlations among geographic, climatic, and soil variables resulted in six clusters (Table 4). Clusters 1 (soil acidification) and 4 ( $\mathrm{K}$ availability) each included four to six correlated soil variables. We selected the $\mathrm{Ca} / \mathrm{Mg}$ ratio of the $\mathrm{B}$ horizon and the $\mathrm{K} / \mathrm{Mg}$ ratio of the $\mathrm{H}$ horizon respectively, to represent these clusters for modelling. Cluster 2 included mainly variables correlated to temperature which we chose to represent by annual temperature for modelling. Site index was also included in this cluster. Cluster 3 comprised variables correlated to precipitation which we chose to represent by annual precipitation. TOPEX and FLOWAT formed a cluster by themselves; we selected FLOWAT because it was a little less correlated to the next cluster. WHC remained alone in a cluster.

\section{Influence of tree- and stand-level variables}

From the results of the AIC method (Tables 5 and 6), we found strong evidence that four explanatory variables influenced total mortality rate at the tree level: RP class (difAIC ${ }_{6-1}$ $=721.9)$, species $\left(\right.$ difAIC $\left.{ }_{5-1}=152.3\right)$, injury $\left(\right.$ difAIC $_{4-1}^{6-1}$ $=16.7$ ), and $\mathrm{DBH}$ (difAIC $\left.{ }_{2-1}=11.1\right)$. These results are corroborated by results from the $P$-value method. The RP class ranked first among explanatory variables and explained large variations in the risk of total mortality, especially in the risks of standing death and of stem breakage resulting in death (Fig. 2). As expected, it followed a mortality gradient corresponding to the RP class (hypothesis 5): healthy and good quality trees were much less susceptible to die than the most defective trees (e.g., 4.4 times lower in class 1 than in class 4 ). The risk of mortality also varied among species $\left(2^{\text {nd }}\right.$ rank in difAIC $\mathrm{X}_{\mathrm{x}-\mathrm{y}}$ ), especially for the risk of standing death (Tables 5 and 6; Fig. 3). Shade-intolerant species were much more likely to die standing than other hardwood species. $\mathrm{AB}$ and $\mathrm{SM}$, the most shade-tolerant species in the study, had the lowest risk of standing death. They were closely followed by YB and STH. Indeed, YB and most of the STH are mid-tolerant species and have similar predicted probabilities of standing death which lay between the other studied species or species groups (hypothesis 4). However, YB and STH had significantly different risks of being uprooted or broken but these remained relatively low (Fig. 3). The presence of a logging injury increased a tree's total mortality probability by a factor of 1.4. In particular, it increased the risks of standing death or of being uprooted according to the $P$-value method. However, this evidence was not supported by the AIC method due to a small difAIC $_{4-1}$ (Tables 5 and 6, hypothesis 3). For instance, the 10-year probability of mortality of the reference tree, as in Fig. 2, was $4.3 \%$ without a logging injury but reached $6.2 \%$ if the tree was injured by logging. For its part, DBH mostly influenced the risk of being uprooted (Tables 5 and 6; Fig. 4a), which was greater for larger trees than for smaller ones. Moreover, its effect on total mortality was nearly constant in the $10-40 \mathrm{~cm}$ range, and increased in the $40-70 \mathrm{~cm}$ range (hypothesis 1).

At the stand level, partial cutting reduced the total mortality probability compared to unharvested plots based on the $P$ value method, but this evidence was not supported by the difAIC $_{3-1}$ of -1.2 (Tables 5 and 6, hypothesis 2). For instance, a tree with a $4.9 \%$ mortality probability was evaluated at $4.3 \%$ after a partial cut; a difference that is small in practice. This reduced risk was associated with the risk of standing death. There was strong evidence to support the effect of soil chemical properties, particularly soil $\mathrm{K}$ availability, on the risk of being uprooted (difAIC $_{13-12}=-17.9$, Tables 5 and 6; Fig. 4b; 
Table 5. Variables in each of the 16 candidate models and their AIC values when calibrated for total mortality (Total mort. rate) and each mode of death: standing death (stand. death), uprooting (Upro.), and stem breakage (Stem break.). Presence of a variable in a model is denoted with a 1, and absence with a 0 . AIC values in bold characters indicate the best model within a dataset. Abbreviations: DBH, diameter at breast height; RP, risk-product; Ref., reference model; other abbreviations defined in Tables 1 and 2

\begin{tabular}{|c|c|c|c|c|c|c|c|c|c|c|c|c|c|c|c|c|c|c|c|}
\hline \multirow[b]{3}{*}{ No. } & \multirow[b]{3}{*}{$\begin{array}{c}\mathbf{n} \\
\text { plots }\end{array}$} & \multirow[b]{3}{*}{$\begin{array}{l}\text { Hypo- } \\
\text { thesis }\end{array}$} & \multicolumn{13}{|c|}{ Cluster variables } & \multirow{2}{*}{\multicolumn{4}{|c|}{ AIC }} \\
\hline & & & \multicolumn{7}{|c|}{ Variables } & 1 & 2 & 3 & 4 & 5 & 6 & & & & \\
\hline & & & $\begin{array}{l}\text { D } \\
\text { B } \\
\text { H }\end{array}$ & $\begin{array}{c}\text { D } \\
\text { B } \\
\mathbf{H}^{2}\end{array}$ & $\begin{array}{l}\text { Treat- } \\
\text { ment }\end{array}$ & Injury & Species & $\mathbf{R P}$ & SI & $\begin{array}{c}\text { B hor., } \\
\mathrm{Ca} / \mathrm{Mg} \\
\text { ratio }\end{array}$ & $\begin{array}{c}\text { Annual } \\
\text { temp. }\end{array}$ & $\begin{array}{l}\text { Annual } \\
\text { precip. }\end{array}$ & $\begin{array}{c}\mathrm{H} \text { hor., } \\
\mathrm{K} / \mathrm{Mg} \\
\text { ratio }\end{array}$ & $\begin{array}{l}\text { FLO } \\
\text { WAT }\end{array}$ & $\begin{array}{l}\mathrm{W} \\
\mathbf{H} \\
\mathrm{C}\end{array}$ & $\begin{array}{c}\text { Total } \\
\text { mort. } \\
\text { rate }\end{array}$ & $\begin{array}{l}\text { Stand. } \\
\text { death }\end{array}$ & Upro. & $\begin{array}{c}\text { Stem } \\
\text { break. }\end{array}$ \\
\hline 1 & 930 & Ref. & 1 & 1 & 1 & 1 & 1 & 1 & 0 & 0 & 0 & 0 & 0 & 0 & 0 & 8514.6 & 5942.5 & 2440.3 & 2988.2 \\
\hline 2 & 930 & 1 & 0 & 0 & 1 & 1 & 1 & 1 & 0 & 0 & 0 & 0 & 0 & 0 & 0 & 8525.6 & 5943.4 & 2461.2 & 2994.7 \\
\hline 3 & 930 & 2 & 1 & 1 & 0 & 1 & 1 & 1 & 0 & 0 & 0 & 0 & 0 & 0 & 0 & 8513.4 & 5946.6 & 2444.3 & 2986.3 \\
\hline 4 & 930 & 3 & 1 & 1 & 1 & 0 & 1 & 1 & 0 & 0 & 0 & 0 & 0 & 0 & 0 & 8531.2 & 5946.8 & 2444.8 & 2991.0 \\
\hline 5 & 930 & 4 & 1 & 1 & 1 & 1 & 0 & 1 & 0 & 0 & 0 & 0 & 0 & 0 & 0 & 8666.9 & 6118.6 & 2450.6 & 3012.0 \\
\hline 6 & 930 & 5 & 1 & 1 & 1 & 1 & 1 & 0 & 0 & 0 & 0 & 0 & 0 & 0 & 0 & 9236.5 & 6541.9 & 2435.8 & 3120.8 \\
\hline 7 & 930 & 6 & 1 & 1 & 1 & 1 & 1 & 1 & 0 & 0 & 1 & 1 & 0 & 0 & 0 & 8374.6 & 5904.6 & 2314.9 & 2880.7 \\
\hline 8 & 930 & 6 & 1 & 1 & 1 & 1 & 1 & 1 & 0 & 0 & 1 & 0 & 0 & 0 & 0 & 8372.9 & 5924.4 & 2325.7 & 2924.4 \\
\hline 9 & 930 & 6 & 1 & 1 & 1 & 1 & 1 & 1 & 0 & 0 & 0 & 1 & 0 & 0 & 0 & 8512.7 & 5926.6 & 2415.8 & 2930.0 \\
\hline 10 & 930 & 7 & 1 & 1 & 1 & 1 & 1 & 1 & 0 & 0 & 0 & 0 & 0 & 1 & 0 & 8516.5 & 5943.9 & 2440.0 & 2990.2 \\
\hline 11 & 930 & Full & 1 & 1 & 1 & 1 & 1 & 1 & 0 & 0 & 1 & 1 & 0 & 1 & 0 & 8375.9 & 5906.6 & 2313.0 & 2882.7 \\
\hline 12 & 790 & Ref. & 1 & 1 & 1 & 1 & 1 & 1 & 0 & 0 & 0 & 0 & 0 & 0 & 0 & 5722.5 & 3862.3 & 1735.5 & 2156.4 \\
\hline 13 & 790 & 8 & 1 & 1 & 1 & 1 & 1 & 1 & 0 & 1 & 0 & 0 & 1 & 0 & 0 & 5724.6 & 3860.9 & 1717.6 & 2154.8 \\
\hline 14 & 790 & 9 & 1 & 1 & 1 & 1 & 1 & 1 & 1 & 0 & 0 & 0 & 0 & 0 & 0 & 5704.8 & 3850.1 & 1737.3 & 2153.2 \\
\hline 15 & 790 & 10 & 1 & 1 & 1 & 1 & 1 & 1 & 0 & 0 & 0 & 0 & 0 & 0 & 1 & 5716.1 & 3864.0 & 1732.7 & 2149.9 \\
\hline 16 & 790 & Full & 1 & 1 & 1 & 1 & 1 & 1 & 1 & 1 & 0 & 0 & 1 & 0 & 1 & 5702.1 & 3846.2 & 1718.0 & 2147.4 \\
\hline
\end{tabular}

Table 6. Statistics for the tests of fixed ( $F$-value) and random ( $Z$-value) effects of the selected candidate models, their respective $P$-values, and the ranks of the importance of the variables according to their $P$-value or to their contribution in the reduction of the AIC value. Abbreviations defined in Tables 1, 2, and 5. † Indicates a rank shared by two variables

\begin{tabular}{|c|c|c|c|c|c|c|c|c|c|c|c|c|c|c|c|c|}
\hline \multirow[b]{3}{*}{ Variable } & \multicolumn{4}{|c|}{$\begin{array}{l}\text { Total mortality rate } \\
\text { Model } 11\end{array}$} & \multicolumn{4}{|c|}{$\begin{array}{l}\text { Standing death } \\
\text { Model } 11\end{array}$} & \multicolumn{4}{|c|}{$\begin{array}{c}\text { Uprooting } \\
\text { Model } 13+\text { clusters } 2 \text { and } 3\end{array}$} & \multicolumn{4}{|c|}{$\begin{array}{l}\text { Stem breakage } \\
\text { Model } 11\end{array}$} \\
\hline & \multirow{2}{*}{$\begin{array}{c}\mathrm{F} \\
\text { value }\end{array}$} & \multirow[b]{2}{*}{$\operatorname{Pr}>F$} & \multicolumn{2}{|c|}{ Ranks } & \multirow{2}{*}{$\begin{array}{c}F \\
\text { value }\end{array}$} & \multirow[b]{2}{*}{$\operatorname{Pr}>F$} & \multicolumn{2}{|c|}{ Ranks } & \multirow{2}{*}{$\begin{array}{c}\mathrm{F} \\
\text { value }\end{array}$} & \multirow[b]{2}{*}{$\operatorname{Pr}>F$} & \multicolumn{2}{|c|}{ Ranks } & \multirow{2}{*}{$\begin{array}{c}\mathrm{F} \\
\text { value }\end{array}$} & \multirow[b]{2}{*}{$\operatorname{Pr}>F$} & \multicolumn{2}{|c|}{ Ranks } \\
\hline & & & $\mathbf{P}$ & $\overline{\text { AIC }}$ & & & $\mathbf{P}$ & $\overline{\text { AIC }}$ & & & $\mathbf{P}$ & AIC & & & $\mathbf{P}$ & AIC \\
\hline $\mathrm{DBH}$ & 4.10 & 0.0430 & 7 & $5 \dagger$ & 5.56 & 0.0184 & 7 & & 0.25 & 0.6144 & - & $3 \dagger$ & 1.1 & 0.2947 & - & - \\
\hline $\mathrm{DBH}^{2}$ & 9.23 & 0.0024 & 5 & $5 \dagger$ & 5.20 & 0.0225 & 8 & - & 0.92 & 0.3386 & - & $3 \dagger$ & 3.8 & 0.0511 & - & - \\
\hline Treatment & 5.84 & 0.0157 & 6 & - & 10.13 & 0.0015 & 4 & - & 1.23 & 0.2682 & - & - & 0.5 & 0.4691 & - & - \\
\hline Injury & 18.17 & $<0.0001$ & 4 & 4 & 6.62 & 0.0101 & 6 & - & 2.84 & 0.0919 & - & - & 5.0 & 0.0249 & 5 & - \\
\hline Species & 61.53 & $<0.0001$ & 3 & 2 & 64.34 & $<0.0001$ & 2 & 2 & 3.19 & 0.0125 & 4 & 5 & 5.1 & 0.0004 & 4 & 4 \\
\hline Risk-product & 225.64 & $<0.0001$ & 1 & 1 & 173.65 & $<0.0001$ & 1 & 1 & 4.60 & 0.0032 & 3 & - & 41.4 & $<0.0001$ & 1 & 1 \\
\hline $\begin{array}{l}\text { Annual temp. } \\
\text { (cluster 2) }\end{array}$ & 71.99 & $<0.0001$ & 2 & 3 & 14.11 & 0.0002 & 3 & 3 & 11.49 & 0.0008 & 1 & 1 & 29.3 & $<0.0001$ & 2 & 2 \\
\hline $\begin{array}{l}\text { Annual precip. } \\
\text { (cluster 3) }\end{array}$ & 0.01 & 0.9066 & - & - & 9.58 & 0.0022 & 5 & 4 & 2.87 & 0.0910 & - & 2 & 20.9 & $<0.0001$ & 3 & 3 \\
\hline $\begin{array}{l}\text { FLOWAT } \\
\text { (cluster 5) }\end{array}$ & 0.05 & 0.8237 & - & - & 0.44 & 0.5082 & - & - & - & - & - & - & 0.1 & 0.7528 & - & - \\
\hline $\begin{array}{l}\text { B hor., } \mathrm{Ca} / \mathrm{Mg} \\
\text { ratio (cluster 1) }\end{array}$ & - & - & - & - & - & - & - & - & 0.59 & 0.4409 & - & $4 \dagger$ & - & - & - & - \\
\hline $\begin{array}{l}\mathrm{H} \text { hor., } \mathrm{K} / \mathrm{Mg} \\
\quad \text { ratio (cluster } 4 \text { ) }\end{array}$ & - & - & - & - & - & - & - & - & 10.99 & 0.0009 & 2 & $4 \dagger$ & - & - & - & - \\
\hline Random effect & $Z$ value & $\operatorname{Pr}>Z$ & & & $\mathrm{Z}$ value & $\operatorname{Pr}>Z$ & & & $Z$ value & $\operatorname{Pr}>Z$ & & & $\mathrm{Z}$ value & $\operatorname{Pr}>Z$ & & \\
\hline Cutblock & 6.279 & $<0.0001$ & & & 6.110 & $<0.0001$ & & & 4.947 & $<0.0001$ & & & 4.966 & $<0.0001$ & & \\
\hline
\end{tabular}




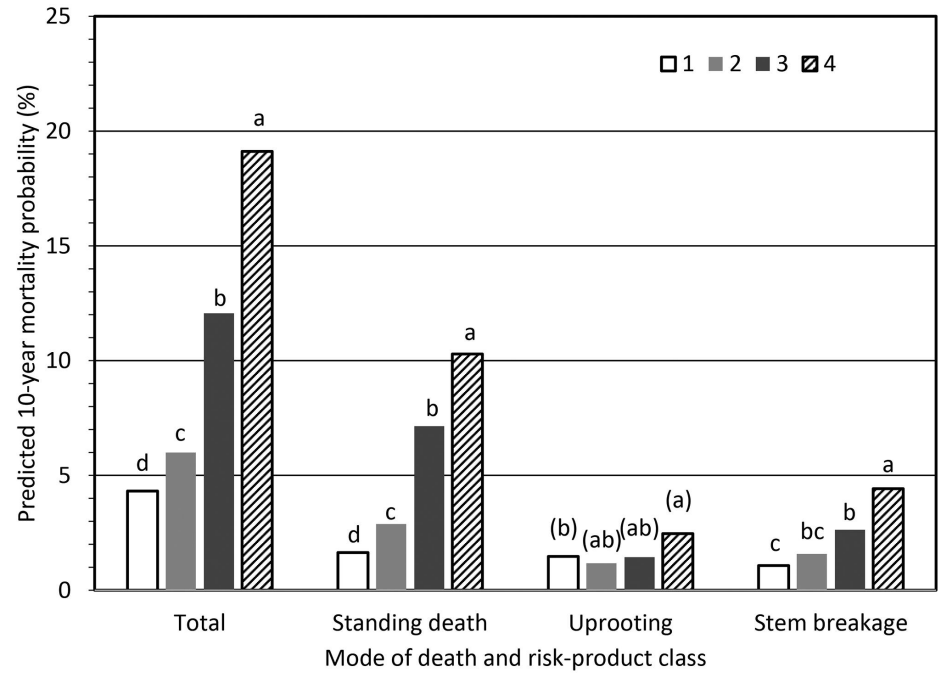

Fig. 2. Predicted 10-year mortality probabilities for a reference tree with varying risk-product classes (1 to 4) according to mode of death. Model 11 was used to calculate the probabilities of total mortality, standing death, and stem breakage. Model 13, with the addition of the effects of annual temperature and annual precipitation, was used to calculate the probabilities of uprooting. Calculations are presented for a reference tree: a $40-\mathrm{cm}$ DBH sugar maple, which is not injured, is located in a treated plot with an index of the accumulation of flowing water in the soil matrix (FLOWAT) of $1600 \mathrm{~m}^{2}$, and with an annual temperature of $2.4^{\circ} \mathrm{C}$, an annual precipitation of $1039 \mathrm{~mm}$, a K/Mg ratio of 2.0 in the $\mathrm{H}$ horizon, and a $\mathrm{Ca} / \mathrm{Mg}$ ratio of 9.5 in the $\mathrm{B}$ horizon. Lowercase letters above the columns indicate significant differences $(P<0.05)$ between risk-product classes for a given mode of death. Letters in parentheses indicate that the AIC did not provide enough evidence to support the effect of the risk-product variable in this model, despite the indications provided by the $P$-value.

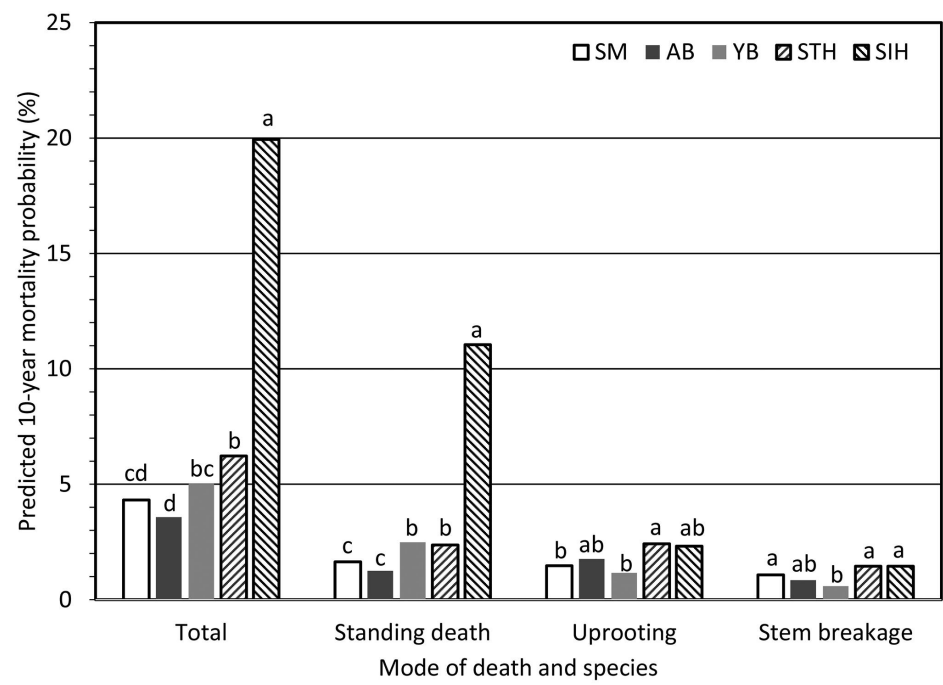

Fig. 3. Predicted 10-year mortality probabilities for a reference tree as defined in Fig. 2, and with the same models used for calculations of the probabilities, but with a risk-product class 1 according to tree species and mode of death. Lowercase letters above the columns indicate significant differences $(P<0.05)$ among tree species for a given mode of death. Abbreviations: SM, sugar maple; YB, yellow birch; AB, American beech; STH, other shade-tolerant hardwoods; SIH, shadeintolerant hardwoods. The complete list of tree species in SIH and STH classes is shown in Appendix. hypothesis 8). Of the two clusters tested in model 13, only the cluster represented by the $\mathrm{K} / \mathrm{Mg}$ ratio of the $\mathrm{H}$ horizon demonstrated an evident effect: the risk of being uprooted was 5.4 times lower at the maximum $\mathrm{K} / \mathrm{Mg}$ ratio (5.6) than at its minimum (0.2). For each unit increase of the $\mathrm{K} / \mathrm{Mg}$ ratio (e.g., from 1 to 2), the risk of being uprooted was reduced by a factor of 1.4 . We did not find strong evidence for the effect of WHC $\left(\right.$ difAIC $_{16-12}=-6.3$; Table 5, hypothesis 10). There was strong evidence that SI affects total mortality (difAIC 14-12 $=-17.7$; Table 5, hypothesis 9), but this effect was considered as an effect of cluster 2 which includes variables correlated to annual temperature.

Influence of geographic and climatic variables There was no evidence of the effect of topography on tree mortality, as expressed by cluster 5 and the FLOWAT variable (Tables 5 and 6 , hypothesis 7). The effects of other geographic variables were included in those of annual temperature or precipitation through clusters 3 and 4, respectively (Table 4). Moreover, annual temperature was the only climatic variable explaining variations in total risk of tree mortality $\left(\right.$ difAIC ${ }_{8-1}=-141.6$; Tables 5 and 6, hypothesis 6). This annual risk was about 3.6 times lower where annual temperature is low (e.g., $2.3 \%$ at $0.8^{\circ} \mathrm{C}$ ) than in a location where annual temperature is high (e.g., $8.1 \%$ at $4{ }^{\circ} \mathrm{C}$; Fig. $4 \mathrm{c}$ ). In addition, annual temperature was always among the first three variables explaining among modes of mortality, and the first one in explaining the risk of uprooting. We did not find strong evidence that annual precipitation contributes to explain total risk of mortality (difAIC $_{9-1}=-1.9$; Tables 5 and 6, hypothesis 6). However, precipitation partly explained the modes of death (Fig. 4d). Indeed, the risk of standing death increased with increasing annual precipitation while the risk of stem breakage and, to a lesser extent, of being uprooted, decreased with increasing annual precipitation.

\section{Discussion}

Influence of partial cutting and tree selection on tree mortality

Cutblocks that were subjected to partial cutting had lower tree mortality compared to unharvested plots. This response reflects one of the main concepts motivating unevenaged forest management in these mature stands, i.e., capturing some of the mortality that is expected to occur before the next harvest. Reduced mortality was attributable, however, to a reduced number of dead trees per hectare following partial cutting, i.e., 49.9 
compared to 65.0 trees $\cdot \mathrm{ha}^{-1}$, rather than to a reduced mortality rate (both $1.25 \%$ year $^{-1}$ ). Consequently, mortality following partial cutting was not reduced as much as determined by Martin et al. (2014) in Ontario, where the rates of mortality were lower after partial cutting $\left(0.21 \% \cdot\right.$ year $^{-1}$ to $0.94 \% \cdot$ year $\left.^{-1}\right)$ in a temperate hardwood forest. The mean annual mortality rate of $1.25 \%$ that we observed was slightly lower than the $1.7 \%$ value reported for unmanaged temperate angiosperm forests around the world (Stephenson and van Mantgem 2005). Overall, mortality in the treated plots was $77 \%$ of that observed in the unharvested plots (63\% to $98 \%$ according to the ecogroup, Table 3 ), and this proportion was lower for larger trees (55\%, ranging from $31 \%$ to $85 \%$, Table 3). Our results agree with those of previous studies. Doyon et al. (1999, 2005) and Angers et al. (2005) reported that treated stands contained $60 \%$ to $89 \%$ of the deadwood measured in unmanaged stands. Overall, the studied stands are old and uneven-aged and, as a result, the effect of senescence is more likely to play a role on tree mortality than self-thinning, regardless of partial cutting.

\section{Influence of tree- and stand-level variables}

At the tree level, four explanatory variables influenced total mortality rate: (1) RP class, (2) species, (3) injury, and (4) $\mathrm{DBH}$. The RP class explained the greatest differences in mortality probabilities, as was previously demonstrated with another dataset covering a similar area (Fortin et al. 2008). Harvesting trees from a higher RP class mainly reduced the risk of standing death and of stem breakage. We hypothesized that vigorous trees were not already affected by, and better able to fend off, damage from various insects and diseases. Yet, a minimal risk of mortality always remained even for the most vigorous trees (e.g., $4.3 \%$ in 10 years, according to Fig. 2). Consequently, even if the best tree selection was applied through tree marking to minimize mortality in selection cutting with a 15- to 25-year cutting cycle, as recommended for the study area (Majcen et al. 1990), some minimal tree mortality will remain to recruit new deadwood in these mature stands which is a valuable component of sustainable forest management. Indeed, the few studies of species diversity following the first selection cutting in hardwood stands have not found major reductions in species that are associated with deadwood (e.g., Moore et al. 2002, Lindner et al. 2006, McKenny et al. 2006).

In terms of tree species effects, mortality probabilities followed a shade-intolerance gradient, with the most shade-tolerant SM and AB having the lowest probabilities. SIH species had the highest probabilities and the more mid-tolerant species, such as YB and the group of other tolerant hardwoods (66\% red maple - Acer rubrum L.), had intermediate mortality probabilities (for shade tolerance, see Burns and Honkala 1990). This result for hardwood species agrees with other studies (Fortin et al. 2008, Martin et al. 2014). The very high mortality probabilities of the SIH species when compared to other hardwood species, supports the common practice in Québec where these species are being harvested in priority when applying partial cutting in tolerant hardwood forests. Other species differences in mortality were not substantial. However, it is worth mentioning that the very low mortality probabilities for $\mathrm{AB}$ were observed during a period when the exotic beech bark disease (see Cale et al. 2017) was absent or nearly absent from the study plots. The vast major- ity of cutblocks were either beyond or at the advancing front of the disease (Shigo 1972) during the measurement period (1995-2009). Because these canker infections can kill a large proportion of mature $\mathrm{AB}$, we expect $\mathrm{AB}$ mortality to increase in future measurements compared to those from the 19952009 period.

For residual trees injured by logging (15\%), the mortality probability increased by a factor of about 1.4 . This result corroborates that of Martin et al. (2014) who reported that mechanical damage from harvesting is a major cause of tree mortality after selection cutting in tolerant hardwood forests, especially for the smallest trees $(\mathrm{DBH}<25.1 \mathrm{~cm})$. Logging injury from felling and skidding operations greatly increase the risk of fungal infection (Benzie et al. 1963) and subsequent tree death. These results also highlight the need to further quantify tree mortality during cutting, as suggested by Tatsumi et al. (2014).

As for the influence of tree size (DBH), graphical evidence shown in Fig. 4a suggests that if total mortality probabilities were higher for the smaller trees, then the differences were small when compared to trees nearing $30 \mathrm{~cm} \mathrm{DBH}$. The general shape of the tree mortality probability curve was a near plateau from 10 to $40 \mathrm{~cm}$, followed by an increase with larger values of $\mathrm{DBH}$. This result does not support the U-shaped trend suggested in hypothesis 1 . Harvesting larger trees can reduce the risk of being uprooted by the wind at the stand level. These trees are normally taller than their neighbors and possess larger crowns, which could render them more susceptible to wind damage. We observed that smaller hardwood trees are more flexible and, by bending, they could better resist the effects of strong winds.

At the stand level, our results show that tree death due to uprooting increased with the reduction of the $\mathrm{K} / \mathrm{Mg}$ ratio of the $\mathrm{H}$ horizon (cluster 4 ). The antagonism between $\mathrm{K}$ and $\mathrm{Mg}$ for plant uptake is well known, $\mathrm{K}$ nutrition being hampered by low soil K/Mg ratios (Mengel and Kirkby 1980). Foliar K deficiency of SM has been diagnosed when the $\mathrm{K} / \mathrm{Mg}$ ratio fell below 0.324 in the humus or below 0.436 in the soil (Ouimet et al. 2013). Values below these thresholds correspond to the highest mortality rate due to uprooting in our study (Fig. 4b). Potassium is mainly involved in photosynthetic activity and photosynthate transport from shoots to roots. A lack of $\mathrm{K}$ tends to reduce these important physiological functions and to decrease the root: shoot ratio in plants (Marschner et al. 1996). The lack of evidence of the effect of soil variables in cluster 1 , dominated by variables related to $\mathrm{Ca}$ saturation and its ratio with $\mathrm{Mg}$, was unexpected, considering the demonstrated effects of base cation depletion on SM health (Moore et al. 2015). However, because unhealthy trees are likely to be classified as high-risk (RP class 3 or 4), it is not surprising that this effect was indirectly captured by the RP classification rather than by the soil variables in cluster 1 . It can take many years between the beginning of the symptoms of crown dieback due to poor soil conditions and the resulting tree death. During this time, a tree can be classified as a high-risk tree and marked for logging. There was no strong evidence of the effect of partial cutting on the mortality probability for every remaining hardwood tree within a stand. Again, this finding can simply be explained by the fact that harvesting trees with a higher RP class mainly reduced the risk of death of the remaining standing trees. 

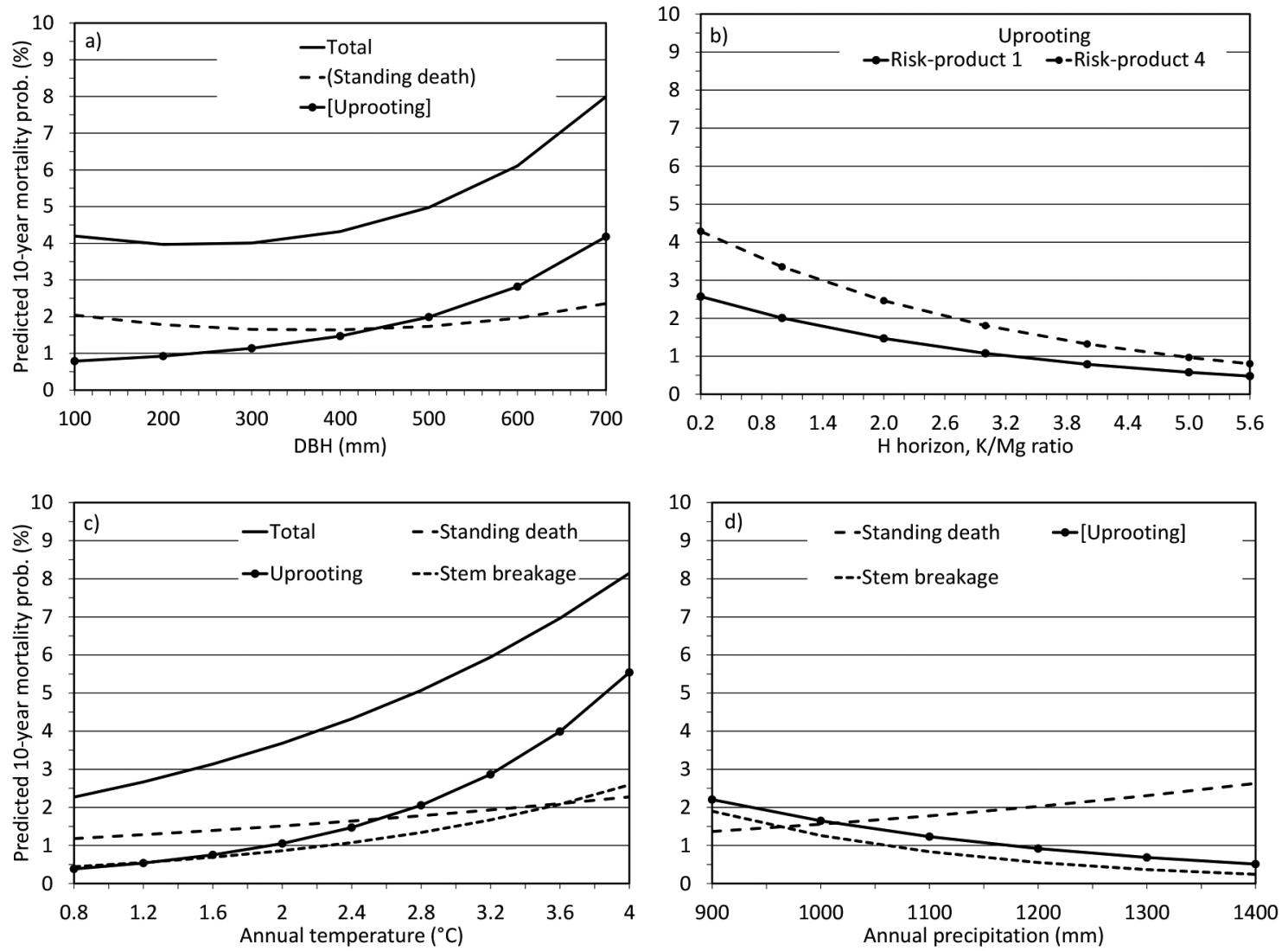

Fig. 4. Predicted 10 -year mortality probabilities according to mode of death for a reference tree as defined in Fig. 2. The same models were used for calculations of the probabilities, but predicted mortality probabilities are shown for: (a) a risk-product class 1 along a gradient of tree size (DBH); (b) a risk-product class 1 or 4 along a gradient of $\mathrm{K} / \mathrm{Mg}$ ratio of the $\mathrm{H}$ horizon, but for the risk of uprooting only; (c) a risk-product class 1 along a gradient of annual temperature; (d) a risk-product class 1 along a gradient of annual precipitation. Mode of death in parentheses indicates that there was enough evidence to support the variable of interest in this model according to the $P$-value method only (Table 6). Mode of death in brackets indicates similar evidence to support the variable of interest according to the AIC method only (Table 6).

\section{Influence of geographic and climatic variables}

Hardwood tree mortality risk varied according to two clusters that included site index, geographic and climatic variables, but that were represented by climatic variables: annual temperature and precipitation (Tables 4 and 6). Annual temperature was one of the most important variables affecting tree mortality by any mode. In particular, it was the most influential variable for the risk of being uprooted (Table 6 and Fig. 4c). Tree height at a given $\mathrm{DBH}$, or site index in this study, is usually inversely correlated with annual temperature due to a shorter growing season $(r=0.47$ between site index and annual temperature). We hypothesize that taller trees, which are more frequent at higher annual temperatures, could be more at risk of being uprooted. Additionally, climatic conditions at lower elevations where temperature is warmer could be more turbulent, with greater risks of ice storms or of heavy snowfall that would increase the mass that a tree must support over a period of time. It is possible that the geography of the lowest elevations favoured the development of intense convective storms during the summer. These storms can sometimes generate damaging wind downbursts as reported in the Great Lakes region (Stueve et al. 2011). Temperature also follows an east-west (low-high) gradient over the study area, which results in higher mortality risks in the warmer, western part of the study area. Regarding annual precipitation, we did not find any effects on total mortality but this variable affected the mode of mortality with more stem breakage and uprooting at lower levels and more standing death at higher levels. Climate could be more turbulent where there is less precipitation, causing more wind damage to trees. Also, root systems could be less efficient in stabilizing trees where there is less precipitation. These results have important implications for evaluating the potential effects of climate change. Had we used only the total mortality model and interpreted the effect of annual temperature alone, we could have concluded that an increase in mean annual temperature would directly increase mortality probabilities over the entire study area. After having partitioned this mortality and considered correlations among variables, we arrived at a more nuanced conclusion: the main association between mortality 
and annual temperature lies in the risk of being uprooted, and the process linking both remains unclear. For instance, it could be due to the presence of taller trees at warmer temperatures, or to different regional climates in the study area, i.e., a more continental and turbulent climate in the western part, and a more maritime and humid climate in the eastern part.

The absence of evidence supporting the effects of topography (FLOWAT or TOPEX) or WHC on tree mortality are thought to be caused by tree species dynamics in northern hardwood and mixedwood stands. Indeed, many species are potential competitors for growing space. When site conditions do not meet all of a species' requirements, then other species can occupy the growing space. In addition, our study variables may have been too coarse to capture the effects of local topography and water availability.

\section{Conclusions}

Selection cutting, as applied to mature stands in this monitoring network, reduced tree mortality in terms of living stems per hectare but did not reduce the proportion of dead trees. Exploring the potential sources of this mortality through its partition indicated no clear evidence that the treatment affects the risk of hardwood tree mortality. Consequently, the probability of mortality for a particular tree was almost the same in the unharvested plots and in those subjected to a partial cut. Partial cutting, however, can have indirect effects on mortality through tree marking and logging injury. In either unharvested or partially cut mature stands, individuals belonging to a higher risk-product classification were the most likely to die, as were shade-intolerant species. These trees were especially likely to die standing, and to a lesser extent, through stem breakage. Thereafter, the second most important contributors to tree mortality were a group of four variables that substantially increased the risk of uprooting: a site with warmer annual temperatures and less annual precipitation, a tree with a larger DBH, especially above $40 \mathrm{~cm}$, and a site with a lower $\mathrm{K} / \mathrm{Mg}$ ratio in the soil $\mathrm{H}$ horizon. The partitioning of mortality and correlations among variables indicate that even though the risk of mortality is higher under a warmer climate in the study area, it is uncertain that warmer annual temperatures resulting from climate change would necessarily increase mortality rates over the whole study area.

Significant mortality risk remains for trees having the lowest mortality probabilities. This indicates that even with the best theoretical tree selection, some mortality should always occur and serve to maintain a minimal level of deadwood, which is a valuable component of sustainable forest management. Moreover, this "baseline" risk of mortality varies regionally over the study area, indicating differences in stand dynamics that are mainly associated with partial disturbances.

\section{Acknowledgements}

We are grateful to many forest technicians who work in the local offices of the Ministère des Forêts, de la Faune et des Parcs du Québec (MFFPQ) for their help in data collection over the years. We are also indebted to Zoran Majcen, Steve Bedard, Sébastien Meunier, and Pierrot Boulay for long-term management of the project. We thank Jean Noël for the spatial analyses and Fig.1, Denis Langlois for methods that were used in the soil chemical analyses, Marie-Claude Lambert for advice on statistical analyses and calculations of climatic variables with BioSIM, and W.F.J. Parsons and Denise Tousignant for English revision. We acknowledge comments from two anonymous reviewers and the associate editor, which improved the quality of this manuscript. This work was funded by the Ministère des Forêts, de la Faune et des Parcs du Québec under project 142332053.

\section{References}

Allen, C.D. et al. 2010. Global overview of drought and heatinduced tree mortality reveals emerging climate change risks for forests. For. Ecol. Manage. 259:660-684. doi:10.1016/j.foreco.2009.09.001 Angers, V.-A., C. Messier, M. Beaudet and A. Leduc. 2005. Comparing composition and structure in old-growth and harvested (selection and diameter-limit cuts) northern hardwood stands in Quebec. For. Ecol. Manage. 217: 275-293. doi:10.1016/j.foreco. 2005.06.008

Bashir, A. and D.A. MacLean. 2015. Effects of species and hardwood-softwood mix on the balance of growth and mortality in old stands in New Brunswick, Canada. For. Ecol. Manage. 358: 192-201. Bauhus, J., K. Puettmann and C. Messier. 2009. Silviculture for old-growth attributes. For. Ecol. Manage. 258: 525-537.

Benzie, J.W., G.A. Hesterberg and J.H. Ohman. 1963. Pathological effects of logging damage four years after selective cutting in oldgrowth northern hardwoods. J. For. 61(10): 786-792.

Bouchard, M., D. Pothier and J.-C. Ruel. 2009. Stand-replacing windthrow in the boreal forests of eastern Quebec. Can. J. For. Res. 39: 481-487. doi:10.1139/X08-174.

Burnham, K.P. and D.R. Anderson. 2002. Model selection and multimodel inference: A practical information-theoretic approach, $2^{\text {nd }}$ ed. Springer-Verlag New York, Inc. 488 p.

Burns, R.M. and B.H. Honkala. 1990. Silvics of North America. 1. Conifers. 2. Hardwoods. Agriculture Handbook 654. U.S. Department of Agriculture, Forest Service, Washington, DC. 877 p.

Cale, J.A., M.T. Garrison-Johnston, S.A. Teale and J.D. Castello. 2017. Beech bark disease in North America: Over a century of research revisited. For. Ecol. Manage. 394:86-103. doi: http:// doi.org/10.1016/j.foreco.2017.03.031.

Canham, C.D. and L. Murphy. 2017. The demography of tree species response to climate: Sapling and canopy tree survival. Ecosphere 8(2): e01701. doi: 10.1002/ecs2.1701.

Chapman, L. 2000. Assessing topographic exposure. Meteorol. Appl. 7: 335-340.

Doyon, F., D. Gagnon and J.-F. Giroux. 2005. Effects of strip and single-tree selection cutting on birds and their habitat in a southwestern Quebec northern hardwood forest. For. Ecol. Manage. 209: 101-115.

Doyon, F., J.-P.L. Savard, D. Gagnon and J.-F. Giroux. 1999. Snag characteristics and use as woodpecker drilling sites in harvested and non-harvested northern hardwood forests. In: A.W. Diamond and D.N. Nettleship (eds). Biology and conservation of forest birds. pp. 103-114. Society of Canadian Ornithologists, Special publication No. 1. Fredericton, NB (Canada).

Flewelling, J.W. and R.A. Monserud. 2002. Comparing methods for modelling tree mortality. pp. 168-177. In: N.L. Crookston and R.N. Havis (compilers). Proceedings, Second Forest Simulator Conference, 12-14 February 2002, Fort Collins, CO. USDA Forest Service, Rocky Mountain Research Station, Ogden, UT. RMRS-P-25.

Fortin, M., S. Bédard, J. DeBlois and S. Meunier. 2008. Predicting individual tree mortality in northern hardwood stands under uneven-aged management in southern Québec, Canada. Ann. For. Sci. 65(2): 205. doi: 10.1051/forest:2007088

Franklin, J.F., H.H. Shugart and M.E. Harmon. 1987. Tree death as an ecological process. BioScience 37(8): 550-556.

Franklin, J.F., et al. 2002. Disturbances and structural development of natural forest ecosystems with silvicultural implications, using Douglas-fir forests as an example. For. Ecol. Manage. 155: 399-423. 
Gauthier, M.-M., F. Guillemette and S. Bédard. 2015. On the relationship between saplings and ingrowth in northern hardwood stands. For. Ecol. Manage. 358: 261-271.

Gitlin, A.R., C.M. Sthultz, M.A. Bowker, S. Stumpf, K.L. Paxton, K. Kennedy, A. Muñoz, J.K. Bailey and T.G. Whitham. 2006. Mortality gradients within and among dominant plant populations as barometers of ecosystem change during extreme drought. Cons. Biol. 20(5): 1477-1486.

Guillemette, F., S. Bédard and M. Fortin. 2008. Evaluation of a tree classification system in relation to mortality risk in Québec northern hardwoods. For. Chron. 84(6): 886-899. doi: 10.5558/tfc84886-6 Guillemette, F., M.-C. Lambert, M.-M. Gauthier and S. Bédard. 2013. Effets réels décennaux des coupes de jardinage pratiquées de 1995 à 1999 dans un contexte opérationnel. Gouv. du Québec, min. des Ress. nat., Dir. de la rech. for., mémoire $n^{\circ} 168.34$ p. Available from: http://www.mffp.gouv.qc.ca/publications/forets/connaissances/recherche/Guillemette-Francois/Memoire168.pdf [accessed 3 March 2017].

Hamilton, D.A. 1986. A logistic model of mortality in thinned and unthinned mixed conifer stands in northern Idaho. For. Sci. 32(4): 989-1000.

Hansen, A.J., T.A. Spies, F.J. Swanson and J.L. Ohmann. 1991. Conserving biodiversity in managed forests. BioScience 41: 382-392.

Hicke, J.A., et al. 2012. Effects of biotic disturbances on forest carbon cycling in the United States and Canada. Glob. Change Biol. 18: 7-34.

Holzwarth, F., A. Kahl, J. Bauhus and C. Wirth. 2013. Many ways to die - partitioning tree mortality dynamics in a near-natural mixed deciduous forest. J. Ecol. 101: 220-230.

Lindner, D.L., H.H. Burdsall Jr. and G.R. Stanosz. 2006. Species diversity of polyporoid and corticioid fungi in northern hardwood forests with differing management histories. Mycologia 98: 195-217. Lines, E.R., D.A. Coomes and D.W. Purves. 2010. Influences of forest structure, climate and species composition on tree mortality across eastern US. PLoS ONE 5(10): e13212. doi: 10.1371/ journal.pone.0013212

Logan T., I. Charron, D. Chaumont and D. Houle. 2011. Atlas de scénarios climatiques pour la forêt québécoise. Ouranos and Ministère des Ressources naturelles et de la Faune. 55 p. Available from: https://www.mffp.gouv.qc.ca/publications/forets/connaissances/rec herche/Houle-Daniel/AtlasOuranos.pdf [accessed 27 April 2017, in French].

Majcen Z., Y. Richard, M. Ménard and Y. Grenier. 1990. Choix des tiges à marquer pour le jardinage d'érablières inéquiennes, Guide technique. Gouv. du Québec, min. de l'Énergie et des Res., Dir. de la rech. for., Mémoire n 96.96 p.

Mannan, R.W., E.C. Meslow and H.M Wight. 1980. Use of snags by birds in Douglas-fir forests, Western Oregon. J. Wild. Manage. 44: 787-797.

Manion, P.D. 1981. Tree disease concepts. Prentice-Hall Inc., New Jersey. 399 p.

Marschner, H., E.A. Kirkby and I. Cakmak. 1996. Effect of mineral nutritional status on shoot-root partitioning of photoassimilates and cycling of mineral nutrients. J. Exp. Bot. 47: 1255-1263.

Martin, A.R., J.P. Caspersen, M.M. Fuller, T.A. Jones and S.C. Thomas. 2014. Temporal dynamics and causes of postharvest mortality in a selection-managed tolerant hardwood forest. For. Ecol. Manage. 314: 183-192.

McElhinny, C., P. Gibbons, C. Brack and J. Bauhus. 2005. Forest and woodland stand structural complexity: Its definition and measurement. For. Ecol. Manage. 218: 1-24.

McKenny, H.C., W.S. Keeton and T.M. Donovan. 2006. Effects of structural complexity enhancement on eastern red-backed salamander (Plethodon cinereus) populations in northern hardwood forests. For. Ecol. Manage. 230: 186-196.

Mengel, K. and E.A. Kirkby. 1980. Potassium in crop production. Advances in Agronomy 33: 59-110.
Moore, J.-D., R. Ouimet, C. Camiré and D. Houle. 2002. Effects of two silvicultural practices on soil fauna abundance in a northern hardwood forest, Québec, Canada. Can. J. Soil Sci. 82: 105-113.

Moore, J.-D., R. Ouimet, R.P. Long and P.A. Bukaveckas. 2015. Ecological benefits and risks arising from liming sugar maple dominated forests in northeastern North America. Environmental Reviews 23(1): 66-77. doi: 10.1139/er-2014-0048.

Murtaugh, P.A. 2014. In defense of $P$ values. Ecology 95(3): 611-617.

Nyland, R.D. 1996. Silviculture: Concepts and Applications. McGraw Hill, NY. 366 p.

Ouimet, R., J.-D. Moore and L. Duchesne. 2013. Soil thresholds update for diagnosing foliar calcium, potassium, or phosphorus deficiency of sugar maple. Comm. Soil Sci. Plant Anal. 44: 2408-2427.

Régnière, J. and R. Saint Amant. 2008. BioSIM 9 - Manuel de l'utilisateur. Service canadien des forêts, Centre de foresterie des Laurentides, Québec. Rapport d'information LAU-X-134f. 74 p.

Reid, A.M., W.K. Chapman and C.E. Prescott. 2016. Comparing lodgepole pine growth and disease occurrence at six Long-Term Soil Productivity (LTSP) sites in British Columbia, Canada. Can. J. For. Res. 46: 595-599. doi: 10.1139/cjfr-2015-0441

Ruel, J.-C. 2000. Factors influencing windthrow in balsam fir forests: From landscape studies to individual tree studies. For. Ecol. Manage. 135:169-178.

Ruel, J.-C., S.J. Mitchell and M. Dornier. 2002. A GIS based approach to map wind exposure for windthrow hazard rating. North. J. Appl. For. 19(4): 183-187.

SAS Institute Inc. 2008. SAS/STAT ${ }^{\oplus} 9.2$ User’s guide. SAS Institute Inc., Cary, NC (United States). Available from: https://support. sas.com/documentation/cdl/en/statug/63033/HTML/default/viewe r.htm\#titlepage.htm. [accessed 3 March 2017].

Saucier, J.-P., A. Robitaille and P. Grondin. 2009. Cadre bioclimatique du Québec. pp. 186-205. In: Écologie forestière. Manuel de foresterie, $2^{\mathrm{e}}$ éd. Ordre des ingénieurs forestiers du Québec. Éditions Multimondes, Québec, Qc.

Shigo, A.L. 1972. The beech bark disease today in the Northeastern U.S. J. For. 70: 286-289.

Stephenson, N.L. and P.J. van Mantgem. 2005. Forest turnover rates follow global and regional patterns of productivity. Ecol. Lett. 8: 524-531.

Sullivan, T.J., G.B. Lawrence, S.W. Bailey, T.C. McDonnell, C.M. Beier, K.C. Weathers, G.T. McPherson and D.A. Bishop. 2013. Effects of Acidic Deposition and Soil Acidification on Sugar Maple Trees in the Adirondack Mountains, New York. Environ. Sci. Technol. 47(22): 12687-12694. doi: 10.1021/es401864w

Stueve, K.M., C.H. Perry, M.D. Nelson, S.P. Healey, A.D. Hill, G.G. Moisen, W.B. Cohen, D.D. Gormanson and C. Huang. 2011. Ecological importance of intermediate windstorms rivals large, infrequent disturbances in the northern Great Lakes. Ecosphere 2(1): art. 2. doi: 10.1890/ES10-00062.1.

Tatsumi, S., T. Owari, H. Kasahara and Y. Nakagawa. 2014. Individual-level analysis of damage to residual trees after single-tree selection harvesting in northern Japanese mixedwood stands. J. For. Res. 19(4): 369-378. doi:10.1007/s10310-013-0418-x

Ung, C.-H., P.Y. Bernier, F. Raulier, R.A. Fournier, M.-C. Lambert and J. Régnière. 2001. Biophysical site indices for shade tolerant and intolerant boreal species. For. Sci. 47: 83-95.

Vanclay, J.K. 1994. Modelling forest growth and yield: Applications to mixed tropical forests. CAB International, Wallingford, UK. 312 p. Waldron, K., J.-C. Ruel and S. Gauthier. 2013. The effects of site characteristics on the landscape-level windthrow regime in the North Shore region of Quebec, Canada. Forestry 86: 159-171.

Westfall, P.H., R.D. Tobias and R.D. Wolfinger. 2011. Multiple comparisons and multiple tests using SAS, $2^{\text {nd }}$ ed. SAS Institute, Cary, NC. 625 p. 
Appendix. List of tree species that comprise the shade-intolerant hardwood (SIH) and shade-tolerant hardwood (STH) groups

Shade-intolerant hardwoods (SIH)

\begin{tabular}{ll} 
Common name & Scientific name \\
\hline Black cherry & Prunus serotina \\
Large-toothed aspen & $\begin{array}{l}\text { Populus grandidentata } \\
\text { Paper birch }\end{array}$ \\
Trembling aspen & Populus tremurifera \\
\end{tabular}

Shade-tolerant hardwoods (STH)

\begin{tabular}{ll} 
Common name & Scientific name \\
\hline American basswood & Tilia americana \\
American elm & Ulmus americana \\
Bitternut hickory & Carya cordiformis \\
Black ash & Fraxinus nigra \\
Butternut & Juglans cinerea \\
Ironwood & Ostrya virginiana \\
Northern red oak & Quercus rubra \\
Red maple & Acer rubrum \\
White ash & Fraxinus americana
\end{tabular}

